\title{
Local Wisdom in Legislation: Find Meaning and Forms in Preservation and Prevention of Environmental Damage
}

\author{
Anak Agung Istri Ari Atu Dewi ${ }^{1}$, Anak Agung Sukranatha ${ }^{2}$, Made Dandy Pranajaya ${ }^{3}$ \\ \{ari_atudewi@unud.ac.id ${ }^{1}$, agung_sukranatha@unud.ac.id ${ }^{2}$, dandypranajaya@unud.ac.id ${ }^{3}$ \} \\ Faculty of Law Udayana University, Bali, Indonesia ${ }^{123}$
}

\begin{abstract}
Local wisdom is a value system that grows in the community which has been carried out for generations which are considered capable of preventing environmental damage and even a powerful value for preserving the environment. Based on these reasons, it is necessary to study more deeply about the regulation of local wisdom and to look for meaning and form of local wisdom in legislation. The research method used is a normative research method with a statue approach and a conceptual approach. The results of this study explain first, there have been clear arrangements regarding local wisdom in efforts to preserve and prevent environmental damage starting from the 1945 Constitution NRI, Law 23 of 2009, PP 57 of 2016, and LHK Ministry Regulation Number P.34 / MENLHK / SETJEN / KUM.1/5/2017 and Bali Provincial Regulation Number 1 of 2017 concerning Environmental Protection and Management. Second, the meaning and form of local wisdom contained in the Laws and Regulations are interpreted as the values of local customary law while the form of local wisdom can be in the form of norms contained in customary law such as the indigenous peoples in Bali in the form of Awig-Awig and Pararem Customary Village.
\end{abstract}

Keywords: local wisdom, legislation, environment

\section{Introduction}

God Almighty created the environment and its contents. Therefore the preservation of the environment must be maintained. In the 1945 State Law of the Republic of Indonesia (hereinafter abbreviated as the 1945 Constitution of the Republic of Indonesia) there is a meaning of protection for the environment. In general, the protection of the environment is found in the fourth paragraph of the Preamble of the 1945 Constitution of the Republic of Indonesia. The fourth paragraph is "Then from that to form an Indonesian State Government that protects the entire Indonesian nation and the entire bloodshed of Indonesia and to promote public welfare, educate life the nation and participate in carrying out world order based on independence, eternal peace, and social justice, then Indonesian national independence is formed in the form of the Republic of Indonesia which has the people's sovereignty based on the One Godhead, just and civilized Humanity, Indonesian unity, and Popularism is led by wisdom of wisdom in consultation/stewardship, and by realizing a social justice for all the people of Indonesia ". Understanding the protection of the environment can also be seen in the Body of the 1945 Constitution of the Republic of Indonesia, specifically in Article 33 paragraph (3) which affirms that the earth and water and natural resources contained therein 
are controlled by the state and used as much as possible for the prosperity of the people. Furthermore, environmental protection is regulated by Law Number 32 of 2009 concerning Environmental Protection and Management. In Law 32 of 2009, it is more emphasized that a good and healthy environment is a human right for every Indonesian citizen, and it is also stated that in carrying out national economic development, it must be based on the principles of sustainable development and environmental insight.

Based on the juridical directives, the protection and preservation of the environment require all aspects of life. The environment is a source of life that must be maintained in order to stay sustainable and sustainable. However, the portrait of the environment in Indonesia shows that there are many environments that have been damaged either caused by natural disasters or because of human actions. In 2002 there was 140 times the incidence of disasters, in 2006 it was 740 times and in 2016 it was 2,542 times. Estimated state losses per year Rp. 30 trillion. Furthermore, losses due to forest fires in 2015 reached Rp. 221 trillion, equivalent to $1.9 \%$ of national economic income. Based on data from the Ministry of Forestry from 1985 to 1997 the reduction in forest area in Indonesia was 22.46 million hectares (ha) or an average of 1,87 million ha per year. Then in 1997-2000, there was a reduction in forest area in Indonesia to 2.84 million per year. The 2000-2005 period showed 1.08 million ha per year. In 2016 there was around 24.30 million ha of critical land. The existence of this data shows that environmental damage occurs due to over-conversion of land.

The portrait of the environment in Bali according to WALHI Regional Bali recorded that the period of 2014 to 2017 had occurred 83 environmental disasters in all regencies/cities in Bali including 31 floods, 19 droughts, 12 landslides, 10 tornadoes, 6 ROBs, 3 flash floods 1 fire forest and 1 tidal wave. The environmental disaster caused fatalities, economic losses, damage to agricultural land.[1]

Based on the portrait of the environment, it shows that the damage and non-maintenance of the environment resulted from natural disasters and human negligence. In this context, a strategy is needed to prevent environmental damage. In the beginning, the strategy that needs to be highlighted is related to policies issued by the Central Government and the Regional Government. Whether these legal policies have been accommodated for protection arrangements that cover the prevention, recovery, and preservation of the environment, especially community-based. Understanding the community in protecting and protecting the environment is inseparable from the value or local wisdom that exists in the community.

Based on Cut Nuraini's research which confirms that local wisdom in the form of the application of customary law in Singengu Mandailing Natal village of North Sumatra is able to manage, protect and preserve environmental functions so that the people of Singengu Mandailing Natal North Sumatra can continue to coexist in a sustainable environment.[2] On the other hand, based on Andry Harijanto Hartiman, states that the condition of the forest is getting damaged because the encroachment of irresponsible people is evidence of the lack of synergy between the government and the existing local wisdom.[2]

Based on the description above, the urgency of this research is related to whether local wisdom has been used to provide protection and preservation of the environment so as to prevent environmental damage. In relation to the urgency above, it is necessary to carry out more in-depth research related to the involvement of local wisdom, especially aspects of regulating local wisdom in legal policies as an effort to prevent and preserve the environment. The deepening of the discussion in this study has the potential that the research team contribute in solving the problems raised, especially in strengthening local wisdom as an effort to provide protection and preservation of the environment in their respective regions, both aspects of regulating local wisdom and the form of local wisdom which can be stated in legal 
policies to lead to legal certainty. Besides that, one important similarity on the convergence of legal systems is the incorporation of what has been regarded as local wisdom.[3]

The problem examined in this study is first, How is the regulation of local wisdom as an effort to preserve the environment and prevent the occurrence of environmental damage in the legislation? Second, what are the meanings and forms of local wisdom regulated in legislation?

The benefits of this research theoretically are that the results of this study are able to contribute to development, especially Law Development by strengthening local wisdom in an effort to preserve the environment and prevent environmental damage.

The practical benefit is to contribute ideas through the results of this research to the parties involved, namely the local government, the community, the Customary Law Community, the activist institutions that are concerned with the protection and preservation of the environment. The thought contribution through this research is expected to be able to provide an understanding that it is important to strengthen local wisdom in efforts to preserve, protect and prevent damage to the legal environment.

\subsection{Literature Review}

In conducting this research, the literature review that has been carried out is conducting a preliminary study relating to the concepts and theories relating to this research. The concept and theory will be used as an analysis knife for the problems raised. The concepts used in this study are:

\subsubsection{Concept}

\subsubsection{Concept of Legislation}

Legislation is an important component in the unity of the national legal system must be built and formed in an integrated manner to guarantee that the development of the national legal system can run regularly, have legal certainty and provide benefits for fulfilling the need for justice and prosperity in accordance with the opening mandate 1945 Constitution of the Republic of Indonesia. The legislation is said to be a product of public policy which is a political commodity that concerns the public interest.[4] The legislation is interpreted as a written regulation that contains generally binding legal norms and is established or stipulated by state institutions or authorized officials through the procedures stipulated in legislation. Burkhardt Krems argues that the science of legislation is divided into 3 namely the legislative process, legislative methods, and statutory techniques.[4] In Law 12 of 2011, the draft regulation has also been regulated, namely, a written regulation containing generally binding legal norms and established or determined by state institutions or authorized officials through the procedures stipulated in the Laws and Regulations. Furthermore, Bagir Manan provides a general description of the concept of legislation, namely 1) Legislation is a written decision issued by an authorized official or environmental position that contains general binding rules of conduct. 2) legislation is also interpreted as a rule of conduct that contains provisions regarding rights and obligations, functions, status or order. 3) is also interpreted as a rule that has general-abstract or abstract-general characteristics, does not regulate or aim at concrete objects or events.[4] A. Hamid S. Attamimi limits the understanding of laws and regulations as a rule of law established by all levels of the institution in certain forms with certain procedures usually accompanied by sanctions and generally applicable and binding on the people.[4]. Based on understanding the concept of legislation can be identified that the concept of legislation is:

1. In the form of written regulations that have certain forms and formats. 
2. Formed and determined by authorized officials, both at the central government level and at the regional level.

3. The legislation contains rules of behavior and regulating patterns.

4. Aimed at the public.

It should also be stressed that the legislation is compelling. In this context, it can be said that the laws and regulations made by the Government must be oriented towards the welfare of the people who have a binding nature and must be obeyed by the people without exception.[4]

The concept of legislation is very relevant to be used to discuss related to the regulation of local wisdom in an effort to prevent and preserve environmental functions.

\subsubsection{The concept of preservation and prevention of environmental damage}

Environmental preservation does not only require a large quantity but also continuous consistency. This is because the environment is not only taken advantage of for a moment but becomes a large community shelter. Protection and preservation of the environment can be seen in Article $28 \mathrm{H}$ paragraph (1) of the 1945 Constitution of the Republic of Indonesia which stipulates that everyone has the right to get a good and healthy environment. This shows that in the 1945 Constitution of the Republic of Indonesia the guarantee and protection of the environment. This also gives direction to the development of the concept of conservation and environmental protection.[5]

Furthermore, this conservation concept is explicitly regulated in Article 1 number 6 of Law 32 of 2009 concerning Environmental Protection and Management, which emphasizes that environmental preservation is defined as a series of efforts to maintain the continuity of the carrying capacity and capacity of the environment. Furthermore, carrying capacity can be understood as the ability of the environment to support the ability of the environment to support the survival of living things and the balance between nature and humans. In efforts to preserve the environment include the stages of planning, utilization, control, maintenance, supervision, and law enforcement.

Furthermore, the prevention of environmental damage can be understood that there are preventive actions taken by both the government and the community in the protection, management, and preservation of the environment. The government in its efforts to take preventive action on the environment must be based on the basis of its authority and responsibility. Similarly, preventive measures taken by the community must be based on their roles and responsibilities.

\subsubsection{The concept of local wisdom}

In Article 1 number 30 of Law 32 of 2009 concerning Protection and Management of the Environment which affirms that Local Wisdom is the noble values that apply in the order of life of the community to among others protect and manage the environment sustainably. In the law also introduced the principle of local wisdom in environmental management in Indonesia, namely that in an effort to protect and manage the environment must pay attention to the noble values that apply in the governance of people's lives. Furthermore, based on the search for various literature, it can be assumed that local wisdom is the values, norms, laws, and knowledge formed by the teachings of religion, beliefs, traditional values and experiences inherited from ancestors which eventually form the knowledge system local used to solve everyday problems by the community. 


\subsection{Theory}

\subsubsection{State Law Theory}

In the discussion on the regulation of local wisdom in an effort to preserve environmental functions and prevent environmental damage, the theory used is the theory of law from Brian $\mathrm{Z}$ Tamanaha. Brian Z Tamanaha emphasized that there are two versions contained in the law state theory, namely 1) a formal version consisting of 3 retreats namely a) Rule by law, b) Formal Legality, c) Democracy legality. 2) Substantive version consisting of a) individual rights, b) Right of dignity and 6) social welfare.[6] Based on the theory of state law, it can be understood that the formal version of the rule of law concept starts from the concept of rule by law, namely law is defined as an instrument of government action. Furthermore, it developed in the form of formal legality which means that legal concepts are interpreted as general, clear, perspective and definite norms. Furthermore, Tamanaha stated that the latest development of the formal version of the rule of law concept is democracy and legality which is defined as an agreement that determines the content or substance of the law. In this context, Yance Arizona [6] states that the formal concept of the rule of law is aimed at announcing the law by the authorities regarding the clarity of statutory norms. The formal concept of the rule of law is not intended to settle legal decisions on legal reality and not also related to whether the law is good or bad law. Furthermore, in the concept of substantive law state, it can be interpreted that the development of a legal state starts from individual rights, where privacy and individual autonomy and contracts are the most basic foundation, then these developments lead to the principle of rights to personal freedom and/or justice (dignity) and develop into social welfare concepts that contain substantive principles, equality, welfare and continuity of the community. In understanding the concept of the substantive law state wants to move further, namely basic rights are used as the foundation to distinguish which law fulfills basic rights and which law ignores basic rights including the neglect of the basic rights of a marginalized community. Thus it can be understood that the formal concept of the legal state focuses on the feasibility of legal sources and their forms of legality, while the substantive concept of the legal state focuses on the contents of these legal norms.

\subsubsection{Theory of Legal Pluralism}

The understanding of the validity of the law in Indonesia, it seems clear, that in addition to applying state law which Nurjaya [7] referred to as a state law, folk law and religious law are often called religious law. In this context, it can be understood that the legal application of more than one legal system is referred to as legal pluralism. Legal pluralism that shows the condition that more than one legal system or institution exists together in various activities and relationships.[7] The description of legal conditions like this is very thick with the existence of law in Indonesia. Regarding the description of legal pluralism is not a new issue or new study in Indonesia. In simple terms, pluralism is present as a criticism of positivism. There are several ways to understand legal pluralism. First, legal pluralism explains the relation of various legal systems that work in society. Second, legal pluralism maps various laws that exist in a social field. Third, explain the relations, adaptation, and competition between legal systems. Third, legal pluralism shows the choice of citizens to use certain laws when in conflict. From these three perspectives and many other perspectives, it is briefly stated that legal pluralism is a reality in people's lives. In line with that, borrowing a phrase from Brian $Z$. Tamanaha, legal pluralism is everywhere.[7] John Griffiths put forward the concept of weak legal pluralism (weak pluralism) and strong legal pluralism (strong pluralism).[7] Legal pluralism is called weak legal pluralism when the state recognizes the presence of elements of other legal systems outside state law, but these non-state legal systems are subject to their 
application under state law. Meanwhile, strong legal pluralism is present when the state recognizes the existence of non-state law and the legal system has the same enforcement capacity as state law.In this context, it is very appropriate that legal pluralism theory is used to discuss the regulation of local wisdom in efforts to preserve environmental functions and prevent environmental damage. This is due to the interaction between customary law and state law in the formulation of local wisdom norms.

\section{Research Method}

Research is a means or search effort to develop science and technology by finding, and expressing a truth by carrying out an analysis. According to Peter Mahmud Marzuki, "legal research is a process of finding legal rules, legal principles, and legal doctrines in order to answer the legal issues at hand.[8] According to Morris L. Cohen and Kent C. Olson stated that "Legal research is an essential component of legal practice. It is the process of finding the law that governs an activity and materials that explain or analyze that law".[8] Furthermore, Soerjono Soekanto stated that in law there are two types of legal research, namely normative legal research and sociological or empirical legal research.[8] Normative legal research methods, also known as doctrinal legal research and also called library legal research. It is called doctrinal law research because this research is carried out or aimed at written regulations or other legal materials, whereas it is referred to as library research or document study because this research is mostly carried out by libraries or document studies because this research is mostly done on the legal material secondary in the library.[8] In this study, a type of normative research is used by using a statutory approach and conceptual approach.

The sources of legal material used in this study include primary legal material and secondary legal material. The primary legal material used in this study is the applicable legislation and related to the problem under study. The primary legal materials are the 1945 Constitution of the Republic of Indonesia, the level of law, PP, Ministerial Regulations, Provincial Regulations, and Regency / City Regulations. Furthermore, the collected legal materials from primary legal materials and secondary legal materials are processed and analyzed qualitatively. At the processing stage, the legal materials that have been collected are categorized and qualified based on research problems, then systematically arranged according to the framework prepared beforehand. At the analysis stage, legal materials that have been categorized and qualified are analyzed by linking legal materials to one another. Furthermore, the interpretation of the legal material is held to be able to produce conclusions about the problems raised. The interpretation used is related to legal hermeneutics.[8] Legal hermeneutics is essentially a method of interpretation of the legal text, which displays the explicit aspect of the sound of the legal text and the implicit aspect which is the idea behind the legal text. Therefore to get a complete understanding of the meaning of the legal text, it is necessary to understand the ideas behind the formation of legal texts and insight into the current context when the legal texts are applied or interpreted. The truth in legal science is the truth of intersubjectivity, therefore it is important to confirm and confront the theories, concepts, and thoughts of scholars who have authority in their scientific fields regarding thematic research.[8] The overall results of the analysis, then presented descriptively, namely by describing in full all the problems related to the problem under study accompanied by providing reviews critically. 


\section{Results and Discussion}

\subsection{Regulation of local wisdom as an effort to preserve the environment and prevent environmental damage in the legislation}

As explained in the literature review, and efforts to prevent environmental damage, concepts and theories are very important to use in reviewing this. In assessing the regulation aspects of local wisdom in order to prevent environmental damage and in efforts to preserve the environment, it is first seen in the aspects of regulation in legislation. In accordance with Article 7 of Law 12 of 2011 concerning the Establishment of Legislation it is determined that the type of hierarchy of laws and regulations includes: 1945 Constitution of the Republic of Indonesia, the Decree of the People's Consultative Assembly, Acts or Government Regulations in Lieu of Laws, Regulations, Presidential Regulations, Provincial Regulations, and District Regulations / City. Thus in terms of discussing the regulation of local wisdom at the level of legislation starting from the regulation of local wisdom in the 1945 Constitution of the Republic of Indonesia. The regulation of local wisdom in the 1945 Constitution of the Republic of Indonesia is regulated in Article 18 B paragraph (2) which determines that the State recognizes and respects the Customary Law Community Unit along with their traditional rights as long as they are in accordance with the development of the community and the NKRI principles stipulated in the Law. In Article 18 B paragraph (2) the 1945 Constitution of the Republic of Indonesia NRI provides direction to regulate local wisdom in the law and in legal policies for efforts to preserve the environment. Furthermore, the regulation of local wisdom is also regulated in Article 28 I paragraph (3) which confirms that the cultural identity and rights of traditional communities are respected. In Article 32 paragraph (1) it is affirmed that the state guarantees the freedom of the people in maintaining and developing their cultural values. The provisions of Article 32 paragraph (1) of the 1945 Constitution of the Republic of Indonesia are understood that the state gives freedom to develop its cultural values, including in developing the value of local wisdom in efforts to preserve the environment. Based on the understanding of Article 18 B paragraph (2), Article 28 I paragraph (3) and Article 32 paragraph (1) of the 1945 Constitution of the Republic of Indonesia is understood that there are a basis and direction for the country to develop the values of local wisdom in an effort to improve community welfare environmental conservation efforts and prevention of environmental damage. In this context the role of local wisdom in the regulation of legislation that precedes local wisdom as a principle in the formation of legal norms in a subsequent legal regulation.

Clear regulation of local wisdom can be seen in Article 1 number 30 of Law 32 of 2009 concerning Protection and Management of the Environment which confirms that local wisdom is a noble value that applies in the social life system especially in protecting and managing the environment sustainably. In this context noble values which are local wisdom in each region or region are developed for the purpose of protecting and preserving their environment. More assertive about efforts to preserve the environment stipulated in Article 1 number 6 of Law 32 of 2009 emphasizes that efforts to preserve the environment are the efforts of the community and the government in maintaining the carrying capacity and capacity of the environment. In this case, there is a balance between carrying capacity and capacity. Thus in realizing the balance of the carrying capacity and capacity of the environment as an effort to make efforts to preserve the environment, several stages are carried out with mature concepts. The stages of environmental conservation efforts include planning, utilization, control, maintenance, supervision, and law enforcement. In the context of the balance of carrying capacity and 
capacity as stipulated in Article 1 number 6 of Law 32 of 2009, the role of local wisdom is very important and very necessary as a balance of the power to support and accommodate the environment. Local wisdom that is used as an effort to preserve and prevent environmental damage, lives and grows in the environment of indigenous peoples as a community group that is inherently bound by its geographical area and has an attachment to the origin of ancestors and ties to their environment. If it is examined further, the regulation of local wisdom is expressly regulated in Article 63 paragraph (1) letter $t$ which determines that the task and authority of the Regional Government is to establish regional policies related to local wisdom. This shows that local wisdom is a priority in enforcing environmental law, especially in protecting and managing the environment. Besides being regulated in legislation, the development of local wisdom can be carried out by the community relating to the preservation of environmental functions. This is confirmed in Article 70 paragraph (3) letter e of Law 32 of 2009. In the context of the role of society in the development of local wisdom as an effort to preserve the environment, that the community based on noble values that live, grow and develop and apply in people's lives can used in efforts to preserve and prevent environmental damage. The regulation of local wisdom is more concrete and clearly regulated in the Minister of Environment and Forestry Regulation (hereinafter abbreviated as LHK Candy) Number P.34 / MENLHK / SETJEN / KUM.1 / 5/2017 concerning Recognition and Protection of Local Wisdom in Management of Natural Resources and Environment Life. In considering the letter $\mathrm{b}$ which basically outlines the importance of the role of local communities in the management of natural resources and the environment based on local wisdom.

\subsection{The meaning and form of local wisdom in the legislation}

Local wisdom is understood as a system that is contained in the order of political, cultural, economic and environmental life which is found in the midst of the life order of the Indigenous Law Society. The character inherent in local wisdom in the customary law community unit is very dynamic, sustainable and can be accepted by the community unity.

Within the customary law community unit, local wisdom is manifested in a set of customary law, knowledge, and skills as well as values and ethics that govern the unity of indigenous peoples and develop from generation to generation. Understanding of local wisdom as above is very complex and general, but the limits of understanding in this study are limited to understanding the meaning of local wisdom in legislation. To get an understanding of local wisdom in legislation, the right technique to use is legal hermeneutic interpretation techniques. Using legal hermeneutics will clearly reveal the meaning contained in the articles, especially Article which regulates local wisdom. In this study explained the meaning and form of local wisdom contained in Law No. 32 of 2009 concerning Environmental Protection and Management. As previously explained, there is a clear arrangement regarding local wisdom in Law 32 of 2009, but if a deeper meaning is explored in Law 32 of 2009 there can be different understandings related to the meaning and form of local wisdom. On the other hand, seeing the current state of the environment is very alarming. Genetically, environmental crises include water, plants, animals, soil and air. This has experienced a crisis, namely the contamination of the three main technologies, namely: industrial technology, transportation technology, and energy technology, besides that it cannot be separated from human carelessness in conducting natural resource management. In addition, environmental damage is also caused by rapid population growth and is followed by the need for the availability of capacity followed by a demand for the availability of available natural resources. So this is what often causes environmental damage.[9] Regarding this context, the meaning and form of 
local wisdom are customary law in each region. In Bali, the customary law referred to be the value of local wisdom as outlined in the awig-awig and pararem traditional village.

\section{Conclusion}

Regulation of local wisdom as an effort to preserve the environment and prevent the occurrence of environmental damage in the Laws and Regulations is strictly regulated in the 1945 Constitution of the Republic of Indonesia. The regulation regarding the environment is specifically related to the regulation of local wisdom regulated in Law 32 of 2009. It is expressly stated that local wisdom plays an important role in carrying out conservation efforts and preventing environmental damage. Clear arrangements regarding local wisdom in Law 32 of 2009, PP 57 of 2016 concerning Amendments to Government Regulation Number 71 of 2014 concerning Protection and Management of Peat Ecosystems, LHK Candy Number P.34 / MENLHK / SETJEN / KUM.1 / 5/2017 concerning Recognition and Protection of Local Wisdom in the Management of Natural Resources and the Environment gives direction for the Government in establishing legal policies that respond to local wisdom of local communities in each region and Regional Regulation of Bali Province Number 1 of 2017 concerning Protection and Management of the Environment. The meaning and form of local wisdom in the legislation can be understood as the customary law of the local community. Local wisdom in the community becomes a guideline and guide in behaving, including in efforts to preserve and prevent environmental damage, especially in its area. The form of local wisdom that is used as a means of preservation and prevention of environmental damage can be in the form of customary law that exists in the community. In the indigenous people in Bali, the facilities used in carrying out environmental preservation and prevention efforts are in the form of awig-awig traditional villages and pararem traditional village.

\section{References}

[1] "WALHI Bali | Adil \&amp; Lestari.” [Online]. Available: https://walhibali.org/. [Accessed: 05Feb-2017].

[2] C. Nuraini, "Kearifan Lingkungan Dalam Pengelolaan Hutan, Tanah Dan Sungai Di Desa Singengu, Kecamatan Kotanopan Kabupaten Mandailing Natal, Sumatera Utara (Environmental Wisdom on Management of Forest, Soil and River in Singengu Village, Kotanopan District)," $J$. Mns. dan Lingkung., vol. 22, no. 1, pp. 100-105, 2015.

[3] I. G. N. P. Widiatedja, "Incorporating Local Wisdom Into the Consumer Protection Legal Regime: A Comparison Between Indonesia And Australia," Udayana J. Law Cult., vol. 1, no. 1, p. 31, Jan. 2017.

[4] A. Ramdhani and M. A. Ramdhani, “Konsep Umum Pelaksanaan Kebijakan Publik,” J. Publik, vol. 11, no. 1, pp. 1-12, 2017.

[5] P. M. Faiz, "Perlindungan Terhadap Lingkungan Dalam Perspektif Konstitusi," J. Konstitusi, vol. 13, no. 4, pp. 766-787, 2016.

[6] B. Z. Tamanaha, On the rule of law: History, politics, theory. Cambridge University Press, 2004.

[7] I. N. Nurjaya and M. H. SH, "Perkembangan Pemikiran Konsep Pluralisme Hukum," Dikutip dari http//www. huma. co. id, vol. 12, pp. 1-17, 2004.

[8] S. Irianto, Metode Peneltian Hukum: Konstelasi dan Refleksi. Yayasan Pustaka Obor Indonesia, 2009.

[9] H. Thamrin, "Kearifan Lokal dalam Pelestarian Lingkungan (The Lokal Wisdom in Environmental Sustainable)," Kutubkhanah, vol. 16, no. 1, pp. 46-59, 2013. 